\title{
The Kind of Virgin That Keeps a Parrot: Identity, Nature, and Myth in a Painting by Hans Baldung Grien
}

\author{
Bonnie J. Noble \\ University of North Carolina at Charlotte, Charlotte, USA
}

\begin{abstract}
The 16th-century Protestant Reformation shattered the foundations of faith and art. As traditional theology was both besieged and defended, art had to adapt. Of course, a new theology needed new kinds of pictorial extrapolations. But truly, the most interesting change was hidden in plain sight. Subjects that may have looked familiar were in fact utterly new, because subversive ideas and contexts uprooted older meanings. The painting Madonna with Parrots (1533), by Hans Baldung Grien demoted the chaste protectress by transforming her into a flawed, even dangerous, human mother. In the painting, an oddly sultry Virgin shows off her breast, her shoulder, and her chest as a parrot nibbles her neck. The complexities of Baldung's painting underpin debates about the status of the Virgin during the Reformation and the freedom of an artist to tamper with sacred subject matter.
\end{abstract}

Keywords: Virgin, Madonna, Reformation, Witch, Hans Baldung Grien, Renaissance, Albrecht Dürer

Who are you going to believe, me or your own eyes? —Chico Marx, Duck Soup (1933)

...it is more fruitful to ask how works of art pose problems and provoke reflection rather than to ask how they call forth unequivocal judgments of condemnation or praise. -Margaret Carroll,

Painting and Politics in Northern Europe (2008)

\section{Introduction}

The "Madonna with Parrots" (Germanisches National museum, Nuremberg) of 1533 by Hans Baldung Grien (1484/5-1545) presents the Virgin Mary in half length in the company of a parrot and a parakeet (see Figure 1). ${ }^{1}$ The "Madonna with Parrots" may at first seem to be a fairly familiar, 16th-century, half-length Madonna, the likes of which appear in both Italy and the North. A young Virgin Mary with thin features and long hair holds Christ at her breast while an angel peeks over her right shoulder. Yet, after a moment or two, the painting starts to look odd. A Congo African Gray Parrot (Psittacus erithacus) perches on the Virgin's shoulder (It appears deceptively green in reproductions) and nibbles at her neck. The Virgin acquiesces to this unusual exchange by inclining her head, a gesture that moves beyond mere tolerance to complicity. She appears more responsive to the parrot's advances, and more engaged with the viewer, with whom she locks eyes, than

Bonnie J. Noble, Ph.D., associate professor, Department of Art and Art History, University of North Carolina at Charlotte.

${ }^{1}$ Albrecht Dürer did business with traders in Antwerp, exchanging drawings for bird feathers and parrots, among other things Baldung may have known live parrots as well, see Weber am Bach (2006, p. 131). The picture is dated 1533 on the frame. It was acquired by the Germanisches National museum in 1525 but has no clear provenance (Weber am Bach, 2006, p. 113). 
with her son, to whom she pays no attention. A Ring Necked Parakeet, (Psittacula krameri), either a juvenile or a female because of the faint color of the neck ring, gazes up at the Virgin from the lower left corner. ${ }^{2}$ The parakeet anchors a diagonal across the body of the Virgin, leading the viewer's eye from lower left to upper right, along the line implied by the Virgin's pale arm and hand, toward the breast and up to the Gray Parrot on the upper right. The Virgin's exposed flesh fills much of the composition, as she positions her right hand at her chest. This arrangement of motifs identifies the birds as attributes of the Virgin, not of Christ. The Gray Parrot rests against her skin, not her garment, making the contact all the more sensual. The vulnerability of Mary's exposed neck, her beckoning glance, the attention drawn to her skin, not to mention the menacing expression of the angel in the upper left corner, disconcert the beholder.

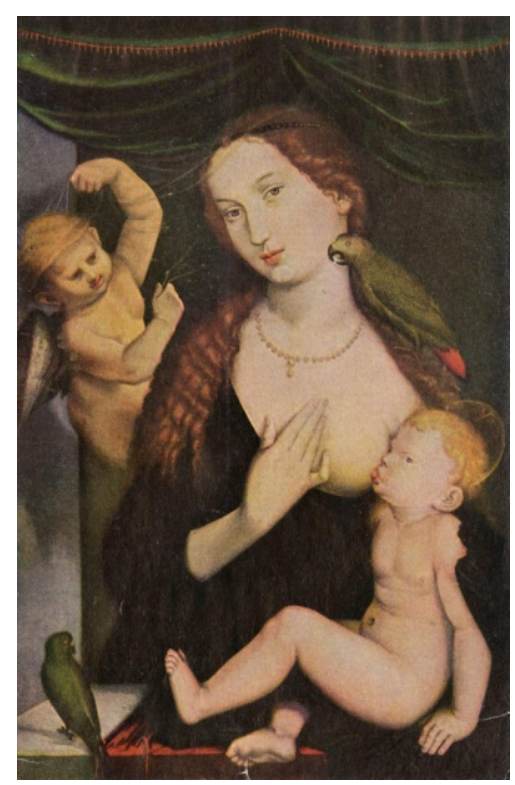

Figure 1. Madonna with Parrots. ${ }^{3}$ Source: adapted from wikimedia. Germanisches National Museum, Nürnberg. Foto: D. Messberger.

Whatever the nature of this curious Virgin, art historians agree that she is unsettling. ${ }^{4}$ Scholars have provided no satisfactory interpretation of the picture. Some see her as a disguised representation of a classical figure, especially Venus. ${ }^{5}$ Others see this and Baldung's other Madonna images of the period as doctrinally flexible pictures suited for the worship by Catholics and Protestants alike (Heal, 2007, 2001; von der Osten, 1983), while still others see the picture as the exact opposite, as narrowly supportive of the Lutheran Eucharist (Weber am Bach, 2006). Still others see the "Madonna with Parrots" as an aesthetic experiment (Baldung, Marrow, \& Shestack, 1981). One scholar proposes that the painting expresses the thought of the Florentine Neoplatonic philosopher Marsilio Ficino (as cited in Schütte, 2000).

\footnotetext{
${ }^{2}$ On African Gray Parrots, see Pepperberg (2008). Weber am Bach (2006), notes the unusual inclusion of two birds instead of one (p. 131). On Gray parrots as elite gifts in Reformation Germany, see Boehrer (2010 p. 78). Boehrer observe sabout parrot symbolism that in Baldung's painting "the resulting shift arguably reflects tensions in the nature of post-Reformation iconography" (p. 86).

${ }^{3}$ The work of art depicted in this image and the reproduction thereof is in the public domain worldwide. The reproduction is part of a collection of reproductions compiled by The Yorck Project. The compilation copyright is held by Zenodot Verlagsgesellschaft $\mathrm{mbH}$ and licensed under the GNU Free Documentation License.

${ }^{4}$ On the historiography of Baldung, see Weber am Bach (2006, pp. 13-15).

5 The most recent proponent of this position is Weber am Bach (2006, pp. 164-188).
} 
Baldung's Virgin is not simply ecumenical, classical, or aesthetically challenging. The following argument will demonstrate that the Virgin's very nature has been profaned in Baldung's picture. Baldung is famous for making pictures that push against conventions with violence, sexual perversion, titillation, or macabre fascination. In keeping with his proclivity for artistic subversion, Baldung's "Madonna with Parrots" defies the conventions of Madonna imagery. In the context of the aggressive misogyny of much of Baldung's art, this profaned Madonna warns viewers about the dangers of all women, even the Virgin. With their associations of speech without meaning, paradise, and both the Virgin and Eve, parrots communicate sensuality and danger. On the conflicted history of parrot symbolism, see Boehrer's Animal Characters: Nonhuman Beings in Early Modern Literature (2010). Not surprisingly, the paradisiacal and exotic symbolism of the parrot within Catholic tradition is subverted during the Reformation, when the parrot comes to symbolize senseless repetition (pp. 77-87).

The "Madonna with Parrots" shares gestures with traditional representations of Venus, linking the eroticism of the Roman goddess of love to the traditionally chaste Virgin. The Virgin's relationship to Eve is no longer part of the traditional Eve-Mary dichotomy, but becomes sisterly instead.

Thematizing controversial, topical anxieties is a hallmark of the art of Hans BadungGrien. Depicting such provocative subjects helped Baldung distinguish himself from other artists, especially his more famous contemporary, Albrecht Dürer. Specifically, as the author's argument will demonstrate, Baldung brands the "Madonna with Parrots" as his own work by questioning or even depriving her of her holiness, profaning her in the most literal sense. ${ }^{6}$

The author's argument will be based on the following four points: (1) The picture's perplexing mood and iconography coincide with 16th-century anxieties about women, as expressed in imagery related to the later witch hunts; (2) The picture crystalizes theological debate about the status of the Virgin during the Reformation, particularly regarding her loss of holy status and her relationship to Eve; (3) Compositional parallels between Baldung's painting and images of Venus propose conceptual parallels between the Roman goddess of love and the Mother of Christ; and (4) The inclusion of both parrot and parakeet in an unorthodox depiction of the Madonna also helped Baldung consolidate his artistic identity in the context of evolving notions of art in the 16th century.

Hans Baldung Grien (c. 1484/5-1545) spent most of his career in the city of Strasbourg (Brady, 1975, pp. 295-315; Koerner, 1993, p. 357). As a young man, he was employed as an assistant in the workshop of none other than Albrecht Dürer from 1503-1507 (Koerner, 1993, p. 250). ${ }^{7}$ Baldung moved to Strasbourg in 1509 and in 1510 married and established a workshop (Hults, 2005, p. 77). ${ }^{8}$ During his prosperous career, he worked in a variety of media, including painting, drawing, woodcut, and design for stained glass (Baldung, Marrow, \& Shestack, 1981). He was commissioned to paint a grand altarpiece of the Virgin for the altar of the Cathedral in Freiburg, between 1512 and 1516 (Hults, 2005, p. 85). ${ }^{9}$ Much of Baldung’s work in Strasbourg tends to be

\footnotetext{
${ }^{6}$ Other scholars have observed a profanation, or more accurately a secularization, in Baldung's Virgin pictures. See (Weber am Bach, 2006, pp. 14, 16, 143; Bussmann, 1966, p. 132; Hugelshofer, 1969, p. 36).

7 For a succinct overview of Baldung’s biography, see Hults (2005, pp. 75-78).

${ }^{8}$ For a reliable overview of the life and career of Hans Baldung Grien, see Baldung (2009, pp. 115-118) and von der Osten (1983, pp. 13-33).

${ }_{9}$ Hults observes connections between Baldung's witch and Virgin imagery as well. Writing about some of his early drawings of witches and the Freiburg Altar, Hults observes "If Baldung's High Altar venerated the Virgin, these drawings denigrated her inverse in a pornography that reduced intellectuals, artists, and even clerics into a low level-but never so low as the female witch. For in responding to and rejecting such baseness, the male subject reconstructed himself” (Hults, 2005, p. 91). The "Madonna with Parrots” arguably carries out both tasks in a single image, veneration and denigration.
} 
smaller-scale portraits, prints, and delicate drawings whose diminutive dimensions suggest private rather than public viewing. ${ }^{10}$

Though this discussion focuses on Baldung's "Madonna with Parrots", it should be noted that other images of the Madonna from this period by Baldung and other artists begin to show unaccustomed sexuality. ${ }^{11}$ For instance, Gossaert's Madonna from 1527, Prado, Madrid, and Baldung's own "Madonna with Sleeping Christ” (c. 1540), Gemaelde Gallerie in Berlin and Bernaert van Orley, "Holy Family”, 1521, Musée du Louvre. The symbolic meanings of parrots, especially their relationship to deception and the devil strengthen the mood of visual uncertainty in the picture. The exposed flesh and incipient sexuality of Baldung's painting could cause contemporary and 16th-century viewers alike could wonder if the peculiarity of this Virgin is a product of their own imagination, in effect questioning the reliability of what is seen.

\section{Parrots, Parakeets, and Perception}

Parrots and parakeets per se are not unusual in images of the Madonna. It should be noted that parrot (Papagei in contemporary German) and parakeet (Sittich in contemporary German) are not distinguished in medieval German (Weber am Bach, 2006, p. 131). Martin Schongauer's engraving of 1480, Urs Graf's woodcut of 1510, and Jan van Eyck's “Canon Van der Paele” of 1436, Bruges, are but three examples. Surprisingly, two parrots, instead of one are in Baldung's painting; and the parrot and parakeet are not in Christ's hands, but rather are attributes of the Virgin instead, as noted above.

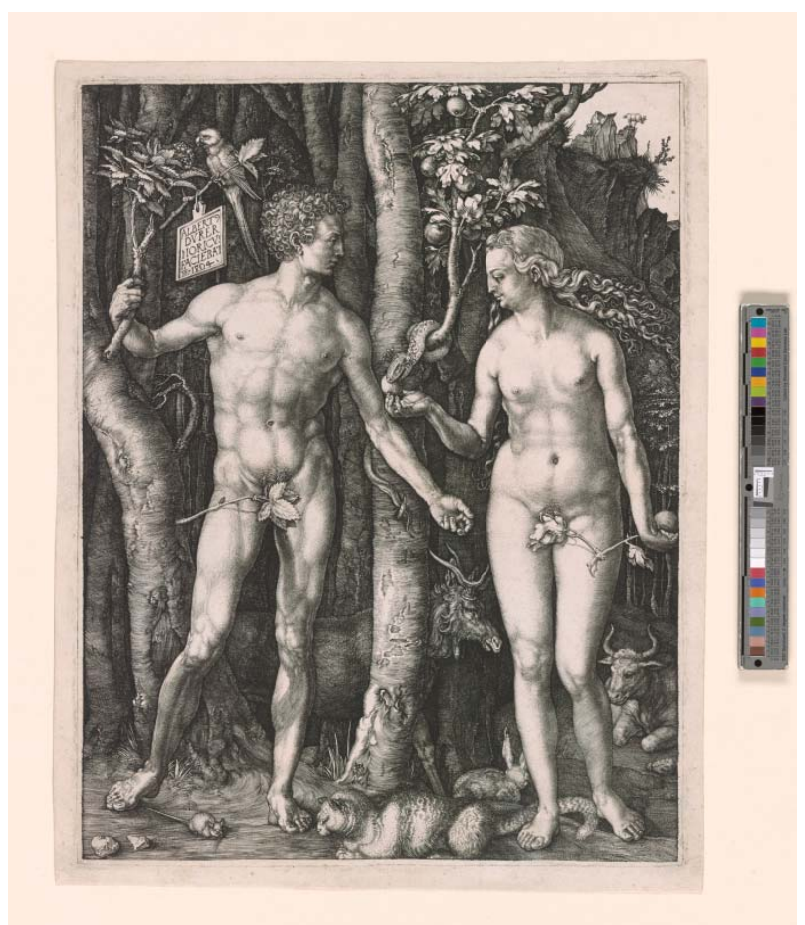

Figure 2. Adam and Eve, $1504 .^{12}$ Source: adapted from Albrecht Dürer, 1471-1528.

\footnotetext{
${ }^{10}$ See the concept of Andactsbilder or devotional images as too limiting (Weber am Bach, 2006, p. 114). See also Hults (1981) on the private nature of the Madonna pictures.

${ }_{11}$ Baldung painted a total of seven Madonna panels. All are reproduced together in Weber am Bach (2006, p. 11).

12 The Pierpont Morgan Library, New York. 2006.80. Purchased as the gift of Eugene V. Thaw, S. Parker Gilbert, Rodney B. Berens, Mrs. Oscar de la Renta, Elaine Rosenberg, T. Kimball Brooker, George L. K. Frelinghuysen, and on the Ryskamp Fund, the Edwin H. Herzog Fund, and the Lois and Walter C. Baker Fun.
} 
Parrots also appear in images of the Fall. One of the most famous examples in Northern art is Albrecht Dürer's 1504 engraving (see Figure 2), where a parrot appears on the tree limb above Dürer's signature. Dürer's 1502 drawing of a parrot reappears in reversed form in his 1504 engraving of the Fall of Humanity (Eisler, 1991, p. 268). The appearance of parrots in scenes of both the Fall and in Madonna pictures suggests that their meaning depends on context. The presence of parrots in images of the Fall and of the Virgin may play on the idea that a parrot's call sounds like Eva/Ave, which in turn refers to the idea of the Virgin as the new Eve. ${ }^{13}$ The call of a parrot may also resemble the Ave of Gabriel at the Annunciation (as cited in Schreiner, 1994, p. 14). Parrots may signify virginity because their feathers are impervious to water. ${ }^{14}$ Or parrots may be associated with paradise lost and regained (Eisler, 1991, pp. 32-33), because they are tropical.

Parrots have other kinds of more negative meanings, for instance Aristotle's association of parrots with sexuality, an idea possibly known among Humanists in the city of Strasbourg where Baldung spent most of his career; and the parrot's red tail also appears phallic. ${ }^{15}$ Martin Luther (1483-1546) saw parrots as symbols of deception. For instance, in the Table Talk, the supposed conversations that took place at table in at Luther's home, the following is attributed to Luther: "I believe the devil resides in parakeets and parrots ...because they can imitate people” (Luther, 1912-1921, pp. 4, 687). ${ }^{16}$ The seemingly human voice may not be human at all. What our ears tell us may be a lie. This quote reveals anxiety about the limitations and deceptions of information acquired through the senses, as we will see in the discussion below.

Such anxieties about perception and truth may have felt familiar and topical to the educated viewers of Baldung's pictures, including his images of witches, for which he is best known, as well as Madonna pictures. The very act of looking becomes anxious if the viewer questions the reliability of perception. The Virgin in the "Madonna with Parrots" appears real. She has mass and volume, plausible human proportions, and believably rendered hair, skin and clothing. And yet, the scenario in its entirety is a fiction. No human eye could ever encounter such a scene. This tension between retinal description and fictitious content is a truism of much Renaissance art. ${ }^{17}$ Angels and devils take up space and walk through believable spaces. Even more complicating is the inescapable truth that the aspects of the image that appear to describe a subject or scene "accurately" are themselves tools of deception. What appears to be an object in space is a two-dimensional illusion that uses variations of color to create an illusion of light and shadow. The "Madonna with Parrots" asks viewers to reconcile the tensions among made-up subject matter, the illusion of reality, and the deceptions that are the tools of that illusion. Even more vexing is the added complication of expectation; visual elements connoting seduction, such as the Virgin's unexpectedly naked shoulder and slit-eyed expression, subvert

\footnotetext{
${ }^{13}$ On the idea that the parrot announces the coming of the Virgin, see Eisler (1991, p. 39), and Weber am Bach (2006, p. 134).

14 On Eva/Ave, see Cohen (2008, pp. 49-50, 112). Eva/Ave supports the broader idea of the Virgin as a complex symbol embracing contradictory meanings. On associations of the parrot with purity and the medieval east, see Cohen (2008, p. 50). On parrots and water, see Eisler (1991, pp. 39, 268).

${ }^{15}$ Weber am Bach (2006) notes also that a peculiar bit of flesh is visible in the parrot's mouth. Sexual associations with parrots extend back Aristotle, and may been known to Baldung (p. 135). For a general discussion of the functions of parrots in various aspects of culture during the Renaissance, see Boehrer (2004, pp. 50-73).

${ }^{16}$ Hereafter cited as WA TR (Weimarer Ausgabe Tischreden). Pepperberg's (2008) ground-breaking research has proven that parrots do not merely imitate but actually understand words and use words to communicate.

${ }^{17}$ Belting (1994) explains the artist's dilemma of representing fictional subjects according to "the laws of perception” where fictional, mythological subjects are depicted to seem optically descriptive (p. 472). Belting (1994) explains the retroactive skepticism that comes from this viewing situation: "The new themes, which had no reality of their own in a literal sense, now affected the way images in general were seen. If what they depicted was based on fiction, the older themes (images of saints and portraits), which were taken literally, could not remain free of ambiguity” (p. 472).
} 
expectations of the innocence of the Madonna.

Christopher Wood elaborates on the issue of convincingly rendered fictions in Renaissance painting in his perceptive interpretation of Dosso Dossi’s “Enchantress” of 1529, Borghese Gallery, Rome (Retrieved from http://commons.wikimedia.org/wiki/Dosso_Dossi\#mediaviewer/File:DossoDossi.jpg). The "Enchantress” shows a woman seated in a landscape in a composition reminiscent of such canonical Madonna images as Raphael's "Madonna of the Meadows", 1505, Vienna, Kunsthistorisches Museum (Retrieved from http://commons.wikimedia.org/wiki/Dosso_Dossi\#mediaviewer/File:DossoDossi.jpg). Like the Virgin in the "Madonna of the Meadows", the enchantress is a single, centrally placed female figure dominating a dramatically receding landscape. But the enchantress is all the Virgin is not. An enchantress appropriating the posture and placement of the Virgin becomes an anti-Madonna, a sacred image inverted (Wood, 2006, p. 166). Rather than an angelic mother in the company of two toddlers, the "Enchantress" is accompanied by such disconcerting objects, including the shrunken bodies of what may be her victims in the upper left corner, and armor in the lower left corner, perhaps atrophy from one of her casualties.

The identity of this Enchantress is uncertain. She may be a version of Circe (see Yarnall, 1994), the goddess who transformed the companions of Odysseus into swine (Odyssey 10: 135-12: 156). She may also be a figure derived from Orlando Furioso of 1516, a poem by Ludovico Ariosto, court poet in Ferrara. In the poem, an evil sorceress puts a spell on men, and a good sorceress reverses the spell. What is most curious about the Enchantress is her impassive expression and the ambiguity of status, neither clear. Even if we do not accept that she is based on Ariosto's poem, the viewer cannot know if she is doing evil or good. Are the shrunken figures hanging from the tree about to be rescued? Or are they recent victims of sorcery? The picture offers no clue (Wood, 2006; Bulfinch, 2004 PDF; Zika, 2002).

A circle forms a boundary on the ground surrounding her. This functional boundary proposes two distinct worlds, one inside and another outside the circle. For Wood, this frame postulates a "real" world outside the fictitious world within a circle (Wood, 2006, p. 166). The circle also mimics the magic circle in Hans Schäufelein's 1511 woodcut, a picture that that catalogs the manifestations of witchcraft.

Other elements of "The Sorceress" are not what they seem. The captured souls put their hands together as though in prayer (Wood, 2006, p. 166), but these bewitched male figures pray to a figure with unholy supernatural power, in a parody of Christian devotion to the Virgin.

The Dossi image, like the Baldung's "Madonna with Parrots", confuses expectations and renders familiarity strange by playing on the same dichotomy of witch and Virgin. The viewer of Baldung's painting must wonder who this woman is, and this anxiety of not knowing is the heart of the meaning of the picture.

\section{Strasbourg and the Reformation}

The city of Strasbourg where Baldung spent most of his career became Lutheran in the course of the early 1520s. ${ }^{18}$ The Reformation was still a new movement in 1533 when the "Madonna with Parrots" was painted. In a Protestant context, the Virgin remained an important figure, though her duties and status were different than they had traditionally been. As scholarship has shown, Luther himself continued to honor the Virgin, but with important provisos. For Luther, the Virgin deserved admiration because of her humility and acceptance of grace (Graef, 1963, p. 8), the defining experience of his theology. The Virgin's extraordinary acceptance of

\footnotetext{
${ }^{18}$ On December 1, 1523, only Evangelical preaching was permitted. In 1524, the Mass was held in German and the Eucharist was
} given in both kinds. Clerics could marry and monasteries were closing. Weber am Bach (2006, p. 54). 
grace renders her worthy of admiration, but, most importantly, she is definitely and absolutely not an object of devotion (Tappolet, 1962, pp. 58-77). For Luther, the Virgin was always and simply a human woman, nothing more.

Artists coped with religious change by adapting their subject matter to suit Lutherans or Catholics, or they produced images that were flexible enough to accommodate a range of viewers. This was clearly the case with the flagship artist of the Lutheran Reformation, Lucas Cranach the Elder. ${ }^{19}$ The hallmark of Cranach's Madonna images is their flexibility, their ability to suit viewers with a range of religious sympathies. ${ }^{20}$ Cranach adjusted his range of subjects to exclude certain types of Mariological images that have no basis in scripture. Luther disapproved of such subjects vehemently (Wittmann, 1998). ${ }^{21}$

The categories of Lutheran and Catholic were fluid in the mid-sixteenth century, so it is not surprising that pictures accommodated the expectations of viewers with various, inchoate, and shifting beliefs. ${ }^{22}$ Like Cranach, Baldung continued to paint Madonna pictures in this Protestant city (Weber am Bach, 2006, pp. 20-31), although it is possible that he could have been painting for Catholic patrons as well.

The most comprehensive study of Baldung's Madonna panels by Weber am Bach, cited above postulates a surprisingly narrow function for the "Madonna with Parrots". Specifically, she contends that the picture relates explicitly to the Synod of 1533, which declared opposition to those who doubted the dual nature of Christ. Legislation against these skeptics that came out in 1533, the same year the "Madonna with Parrots" was painted. For Weber am Bach, the "Madonna with Parrots" defends the dual nature of Christ by showing his human need to nurse (Weber am Bach, 2006, pp. 115-118).

The author would respectfully take issue with Weber am Bach's interpretation. Such a narrow, doctrinal function of the picture is implausible for myriad reasons. First, her argument falls back on an iconographic trap of making a text primary and reducing the picture to a mere conduit of a theological point. This approach buries the power of images and their own, meaning-generating discourse, as scholars such as Craig Harbison and James Marrow among others have demonstrated resoundingly (Harbison, 1985). Simply because a text and a picture emerge in the same year and city does not mean that they correlate directly. Even in a small 16th-century city with limited production of texts and pictures relative to contemporary output, not every word and image relates to every other. Second, Weber am Bach's argument overlooks the differences between public and private display. The dimensions of the picture, plus the tradition of private viewing of Madonna pictures

\footnotetext{
${ }^{19}$ On Luther's theology, see his famous treatises, which map out the fundamentals of his theology. They include The Babylonian Captivity of the Church, which attacked the Catholic sacraments, especially the mass (Luther, 1955-1986, pp. 11-57); The Freedom of a Christian, which explains and defines Christian faith (Luther, 1955-1986, pp. 333-377); and To the Christian Nobility of the German Nation, which calls upon the German rulers to reform the church (Luther, 1955-1986, pp. 115-217).The ideas sola gratia (grace alone) sola fides (faith alone) and sola scriptura (scripture alone) epitomize Lutheran theology, as in the famous slogan “Justification by faith through grace”. Luther’s theological universe rested upon this idea. See Lohse (1986, pp. 149-150) and Dillenberger (1961, p. xiii).

${ }^{20}$.Wittmann (1998) explores the shifting valences of iconographic meaning in different theological contexts (p. 180). Christiane Andersson (1981) explains that the persistence of familiar, traditional forms may obscure shifting functions (pp. 43-79). See also Marrow (1986, pp. 150-69), on the importance of pictorial function. Goedde (1989) explains how observing systematically repeated and omitted motifs assists interpretation, especially in the absence of textual evidence.

${ }_{21}$ On Luther's strident objections to the Virgin as intercessor, see Tappolet (1962, pp. 150-152); Luther (1955-1986, p. 257, 276); See also Düffel (1968, p. 238); and Oberman (1994, p. 242).

${ }^{22}$ Wittmann (1998) explains that Madonna pictures could satisfy the expectations of both Evangelical and Catholic viewers (p. 180). Scholars have noted the intended multiplicity of meaning in Northern works of art. Cranach's paintings are intended to suggest or invoke a spectrum of meanings, possessing, as they do, what Falkenburg calls "semantic openness”. See Falkenburg (1999, p. 356). See also Harbison (1994, pp. 70-81).
} 
argue against the idea that this small painting would declare an official theological precept. Third, the objective of doctrinally driven Lutheran art is to explicate theology as explicitly as possible (Christensen, 1979). ${ }^{23}$ (The intention is reciprocity of word and image, although the effect is of course less predictable ${ }^{24}$ ). As we saw above, the Madonna has a changed status in the Reformation. Because she has herself become ambiguous, a Madonna picture is the least practical way to define and clarify theology; her peculiar mood of the picture would only create more confusion. Fourth and most importantly, connecting the painting to the Synod does nothing to address the strangeness that distinguishes the picture. Yes, the painting asserts Christ's humanity by depicting him nursing, but so do countless other representations of the nursing Virgin. It should be noted that an actual nursing baby does not position his mouth on the breast as Christ does in Baldung's picture. No human baby could draw nourishment in such an unnatural position. As Weber am Bach says herself, Luther admonished against depicting the Virgin with the breast, and the panel resembles the very Catholic of Milchwunder(miracle of milk) of Bernard of Clairvaux (Weber am Bach, 2006, p. 116). None of this clinches a Catholic or Lutheran identity for the picture, but it does underscore the tremendous ambiguity of the image, an aspect that argues against such a narrowly confessional interpretation.

As we learn from Margaret Carroll in the epigraph, art does not by definition or even necessarily offer "unequivocal judgments". Works of art flow through verbal, textual, and pictorial discourses, changing shape with each new response and contribution (Davis, 2009). The "Madonna with Parrots" participates in multiple discourses related to, but not theologically bound to Reformation.

Rather, what the "Madonna with Parrots" is really about is the messy process of the demotion of the Virgin from holy figure to mortal woman, a process initiated in Luther's theology, perpetuated in Cranach's paintings, and furthered in the desacralization of the Virgin in Baldung's picture. Like Cranach, Baldung painted images of the Virgin that could accommodate a range of viewers; Unlike Cranach, shaping confessional issues was not Baldung's priority.

\section{The First Parents and the Mother of God}

Renowned for his meticulously proportional figures, Baldung's older contemporary Albrecht Dürer built his reputation on creating ideals of unassailable human beauty, perhaps most famously in his engraving of Adam and Eveof 1504 (see Figure 2) where the figures display Vitruvian proportions, with postures and gestures that mimic the Apollo Belvedere (c. 330-320 BCE, Vatican Museums) and the Medici Venus (2nd century BCE, Uffizi, Florence). Joseph Koerner has shown that Baldung inverted the perfected human bodies of his older contemporary's by transforming them what amounts to their evil twin. ${ }^{25}$ For instance, Baldung's drawing Death Holding a Banner, c. 1506 Kupferstichkabinett, Kunst museum, Basel mirrors and subverts Adam from Dürer's 1504 engraving by reconstituting the idealized Adam as a rotting cadaver posing in a mirror image. This subversion of Dürer's example allowed Baldungto assert his artistic independence as a macabre reinvention of Dürer. Just as Baldung inverted Adam, he adapted and reinvented the Virgin, also as a way to separate himself from his more famous contemporary (Hults, 2005, 78). The disorienting qualities of the "Madonna with Parrots" come from her gestures, expression, eye contact, and bared shoulder, all of which

23 On Law and Gospel, see pp. 124-130; on Cranach's Reformation altarpieces, see pp. 136-154.

24 On the intended clarity but actual disconnect between word and image in religious art of the Renaissance, see Berdini (1997) and Noble (2009).

${ }^{25}$ Koerner (1993) calls his chapter “Dürer Disfigured” Moment (pp. 249-273). 
subvert her purity, so much so that the traditional Eve-Mary dichotomy topples. In the "Madonna with Parrots" the relationship actually becomes sisterly. Baldung flaunts the rules of representation of the Madonna by connecting her formally to Eve.

In Baldung's chiaroscuro woodcut of 1511 (see Figure 3), both Adam and Eve gaze at the viewer, while they enact the Fall, turning towards the beholder to expose the full spectacle of their nudity. Adam positions himself behind Eve, placing her between himself and the viewer as though to display what tempted him. The eye contact between the figures and the beholder beckons and tempts the viewer, encouraging him (Baldung's patrons were male) to participate in the seduction, or derive voyeuristic pleasure from the scene, or perhaps to summon his strength to learn from Adam's mistake and resist. Playing on this most ancient seduction, the "Madonna with Parrots" locks eyes with the viewer, her hand on her breast in a gesture paralleling Adam's hand caressing Eve. Just like Eve, her narrow-eyed expression and exposed flesh encourage carnal thoughts. Similar parallels exist between the "Madonna with Parrots" and Baldung's much later painting of "Adam and Eve” of 1530-1540 (MuseoThyssen-Bornemisza, Madrid, not illustrated) where Eve regards the viewer with inclined head and a direct gaze, and a touch draws the beholder's eye to the breast.

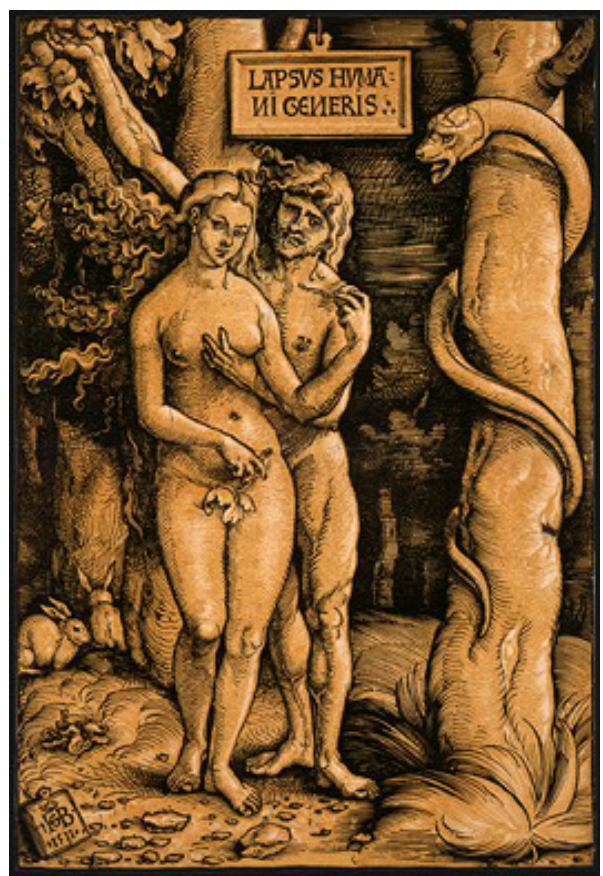

Figure 3. Adam and Eva (chiaroscuro woodcut). Sheet: 37.7 x 25.7 cm (14 13/16 x 10 1/8 in). Source: Hans Baldung Grien, 1511, National Gallery of Art, Rosenwald Collection.

The "Madonna with Parrots" not only resembles pictures of Eve, it also differs from earlier versions of "Maria Lactans”, Mary nursing. The exposure of so much of the Virgin's flesh is atypical in images of the Madonna, and certainly more than would be necessary to actually nurse a child. The sultry exposure of flesh along with her angled head and the gaze and nibbling parrot are suited to seduction rather than nursing. The unusual inclusion of two parrots suggests that one may contradict the other, that one may be the Eva and the other the Ave, insisting that the winner of the battle between dangerous and pure women has yet to be resolved (Weber am Bach, 2006, p. 131).

Eye contact itself is not unusual in Madonna pictures, but eye contact combined with the exposed breast 
and exposed shoulder is unfamiliar indeed. This combination of exposed flesh and eye contact also appears in Baldung’s later, Madonna panels, for example, "Madonna with Sleeping Christ” (c. 1540), Gemäldegalerie der StaatlichenMuseenzu Berlin (not illustrated), where the shoulder is uncovered and the breasts are exposed even as the child sleeps rather than nurses. The persistence of these combinations of elements suggests a tendency in Baldung's Madonna pictures to tamper with the Virgin's purity.

If we compare the "Madonna with Parrots” to Robert Campin’s "Virgin by a Fire screen” of 1420 National Gallery, London, we see in Campin's image that the Virgin's eyes are humbly averted ${ }^{26}$ and only her breast and a bit of chest are visible. In Rogier van der Weyden's “Saint Luke Painting the Virgin” of 1440, Boston Museum of Fine Arts, the Virgin's eyes are decorously downcast and only the breast is exposed with no superfluous flesh. A brief look at three of Dürer's Madonna pictures, the "Madonna Nursing", 1503 and the "Madonna with a Half Pear", 1512, both in the Kunsthistorisches in Vienna the 1526 "Madonna with a Pear" (Uffizi) show none of the sensuality of Baldung's "Madonna with Parrots”. The female figures cast their eyes down or at Christ, or nurse discretely.

Baldung's departures from traditional Marian imagery, and the parallels with depictions of Eve, ultimately undermine the Virgin's holiness. In Baldung's image, the Virgin has become, to quote the title of Bridget Heal's dissertation "a woman like any other" (Heal, 2001) human and sexual, ${ }^{27}$ and in Baldung's world, capable of evil. Luther himself insisted that the Virgin is not qualitatively different than anyone else (Tappolet, 1962, p. 58).

Sexuality, along with mortality, defines the humanity of Christ. Steinberg famously contends that Renaissance painting emphasized Christ's sexuality as a way of asserting his humanity. By the Renaissance, Christ's divinity was no longer disputed, but his humanity needed to be reiterated. Displaying the infant Christ's genitals was one way of making the point (Steinberg, 1997, pp. 15-24). A similar insistence on the Virgin's sexuality is at issue in Baldung's picture. If, as Luther himself contends, the Virgin is human, then she also must be sexual. The "Madonna with Parrots" is a human woman, and in Baldung's universe as sexual and dangerous as any other. ${ }^{28}$ The "Madonna with Parrots" awakens the male beholder's desires and reminds him of his fallen state, just as an image of Eve might.

To be sure, medieval theologians, most famously Bernard of Clairvaux, fell in love with a pure Virgin Mary, a rose without thorns. ${ }^{29}$ But the sensuality of Baldung's picture is different, not spiritual love expressed in erotic metaphor, but profanation manifested in sensuality. Baldung's patrons do not fall in love, but rather fight seduction by a human Virgin whose danger rivals Eve.

The effect the Virgin's sexuality may be to reinforce the viewer's own fallen state. ${ }^{30}$ But there are other possibilities. The pleasure of the sexual performance and the recollection of the sin of the first parents create a conflict of expectation and visual experience. This tension, rather than a specific point of doctrine, is precisely the issue in the "Madonna with Parrots". If the "Madonna with Parrots" is flirting with the beholder, what is the beholder to conclude? Hults (2005) rightly contends that when Baldung's male viewers confronted an image of

\footnotetext{
${ }^{26}$ On the role of images as models for actual female behavior, and eye contact specifically, see Bleyerveld (2001, pp. 219-250).

27 On sexuality, mortality, and humanity, see Steinberg (1997).

28 As Schade (1987), explains, any nude woman is a potential witch. Baldung's Virgin appears in a state of undress unnecessary for the practical purpose of nursing, which makes her a potential witch as well (as cited in Hults, 2005, p. 71). See also Schade (1983).

${ }_{29}$ See the sermons by Saint Bernard of Clairvaux on the Song of Songs, in Bernard and Walsch, 1981.

${ }^{30}$ Koerner makes this idea in reference to Baldung (1993, pp. 268-273; 356-357).
} 
feminine wiles, the viewer is offered a sense of superiority because he will not allow himself to be fooled. ${ }^{31}$ He knows not to trust any of the confusing visual cues that duped poor Adam.

Doubting the Virgin's holiness, wondering if what appears to be the Virgin may not be the Virgin after, all are poignantly brought to light in Luther's reaction to the famous event of the Fair Mary of Regensburg. In 1519, the City Council of Regensburg razed the local synagogue and expelled the Jews from the city. As the synagogue was being dismantled, a stonemason fell from the scaffolding but then recovered "miraculously" from his injuries. This miracle was attributed to an image in the city known as the Fair Mary icon, and a new church was to be built in her honor on the site of the former synagogue (Bartrum, 1995; Freedberg, 1989; Baxandall, 1980; Mielke, 1988). Luther famously worried that the miracles of the famous Fair Mary of Regensburg were actually deceptions originating with the devil. He cautioned that Satan could just as easily have caused the wounded man's inexplicable recovery (Düffel, 1968, p. 237). ${ }^{32}$ It would appear that Martin Luther and Chico Marx, quoted in the epigraph, are in agreement; both question the truth of visual experience.

The "Madonna with Parrots" does not redeem Eve; on the contrary, it profanes the Virgin. Formal features such as her eye contact with the beholder, her bare flesh, and the unseemly intimacy with the Gray Parrot, make any pretense of holiness appear ironic. The idea of the compromised Virgin becomes more powerful in the context of the demoted status of the Virgin in the Reformation, of her associations with Eve, and as we will see, in Baldung's representations of witches and Venus.

\section{Virgins and Witches}

Baldung's celebrated and infamous pictures of witches perpetuate a misogyny that would ultimately fuel later witch hunting. The prosecution of witches reached a crescendo in a "golden age" of witch hunting as it was, between 1560 and $1630 .{ }^{33}$ A variation of the misogyny that permeates witch imagery also informs the "Madonna with Parrots".

Images of witches and texts about witchcraft proliferated at the end of the 15th and beginning of the 16th centuries, about two generations before witch hunting gained momentum around $1560 .{ }^{34}$ Dürer's Four Witches engraving of 1497, his first dated engraving, is the first example of a picture of a witch as an independent work

\footnotetext{
31 Hults (2005) sees the viewer as privileged, rather than denigrated (pp. 65, 67, 96), and discussion below.

${ }^{32}$ Luther wrote, "After the Jews were expelled, the devil put himself in their place, and made false signs through the highly praised name of Mary and deceived you as well as many others" (the author's translation of "Der teuffel, nach dem die Juden vertrieben sind, sich selbs an yhre statt, gesezt und duch den hochgelobten namen Maria falsche zeychen thutt und euch sampt vielen anderen betrugt”). See the section dedicated to Luther's letters in $W A, W A B r$, vol. 3, pp. 141-42.

${ }^{33}$ Wolfgang Behringer (2008) correlates the timing of witch hunting with weather conditions in his article "Weather, Hunger, and Fear", in Oldridge's Reader, pp. 74-85). Behrenger (2008) writes "Never before or since have so many people been legally executed in such a grotesque manner as in the years 1560-1630" (p. 81). He calls the period that marked fanatic witch hunting 1560-1630 "Little Ice Age” (p. 75). According to Zika’s (2007) Appearance, Witch trials were uncommon in Strasbourg until 1570 (p. 13). Wood (2006) suggests that witch hunting began in earnest in 1480's. Sullivan (2000) notes the difference between the timing of Baldung's witch images and the momentum of actual witch hunts, and concluded that the images were not actually witches at all. According to Hults (2005), approximately 20,000-25,000 witches were executed in Germany between 1560-1660, though "Germany" is a vague term. According to Koerner (1993), 80\% of the 100,000 witches executed in Europe between 1400-1700 were women. Strasbourg was relatively tolerant; very few witch trials occurred until the seventeenth century.

${ }^{34}$ Hults (2005) implicitly correlates the emergence of witch hunting with the international publication of multiple editions of the witch-hunting manual the Malleus Maleficarum or the Hammer of Witches, between 1487-1520 (p. 66). Witchcraft was a specific crime, involving a pact made with the devil sealed with sex. After the deal was closed witches were believed to meet in groups, renounce God, and practice ritual cannibalism. Zika (2007) explains that witchcraft evolves out of sorcery, but has significant differences. Sorcery is an individual crime, where as witchcraft usually happens in groups. Sorcery aims to achieve what cannot be accomplished otherwise. Evil is the sole motivation for witchcraft (p. 26). An early example of an illustrated text on witchcraft is by Ulrich (Molitor, On Female Witches and Seers, 1490-1510; see Zika, 2007, p. 13).
} 
of art (Wood, 2006, p. 156).

The most notorious text associated with the witch hunts is the Malleus Maleficarum of 1487 by Heinrich Kramer and Jacob Sprenger. The Malleus included a Bull from Pope Innocent VIII as well as a letter of support from Emperor Maximilian. The Bull declares that people had been tempted into witchcraft in the cities of Trier, Cologne, Mainz, Salzburg, Bremen. Those who do not cooperate with inquisitors would be punished or excommunicated. The Malleus became more influential after 1560, when witch hunting was already underway (Hults, 2005, p. 60). ${ }^{35}$

Estimates about the numbers of people who were prosecuted or executed vary widely. One estimate is that 100,000-200,000 people were tried for witchcraft, $75 \%$ of them women, and approximately 10,000 were killed. ${ }^{36}$ Hults estimates that 20,000-25,000 executions of witches occurred in German territories from 1560-1660 (Hults, 2005, p. 57).

Ideas that nurtured fear of witches gestated in broader, inchoate anxieties before actual witch hunts occurred. The delay between the flourishing of pictures of witches and the onset of significant numbers of witch hunts that are between Baldung's print of 1497 and Baldung's successful witch-image production and the surge of witch trials starting c. 1560 suggests a period of incubation of ideas, words and images. This forces us to recognize that pictures such as Baldung's depict stories, extrapolations, and fears, rather than embodying actual practices. The delay also reveals the complexity and interconnectivity of various iterations of related ideas in a range of discourses both pictorial and verbal. As we learn from Margaret Carroll in the epigraph, works of art pose problems, refract dilemmas, and express concerns; their function is indexical rather than conceptually mimetic.

The completion of Baldung's chiaroscuro or tonal woodcut of "Witches Sabbath", of 1510 (see Figure 4) correlates with the artist's establishment as an independent master in Strasbourg (Hults, 2005, p. 77). Baldung's witches are women who have reverted to furious depravity. Symmetry, beauty, and idealized proportion are overturned, becoming imbalance, ugliness, disproportion, and the most vulgar public display. As Charles Zika astutely explains, stereotypes of female nurturing are explicitly inverted. Rather than preparing nourishing food, they boil up noxious brews to poison and kill, the repulsive ingredients themselves derived from the blood of babies according to lore (Zika, 2007, p. 74). ${ }^{37}$

Zika (2007) proposes that misogynist witch imagery was motivated by fascination with female nurturing and sexuality; that the wild flying hair connects the figures to torches, referencing a gaseous internal environment, i.e. that women's bodies boil like cauldrons and are capable of both nurturing and destruction. Like other scholars, Hults (2005) sees scape goating for misfortunes involving weather, illness, and famine. ${ }^{38}$ The poor and the ill took revenge on witches, and authorities complied perhaps to keep the peace (Behringer, 2008, p. 75). Witchcraft originated as a medieval heresy (Behringer, 2008, pp. 19-22).

\footnotetext{
${ }^{35}$ Hults is the scholar who discusses the Malleus in explicit connection to Baldung. See also Koerner (1993).

${ }^{36}$ Statistics cited in note 7, "Great Witch Hunt" in Brady, Handbook of European History, 1996.

37 Zika explains that riding is gendered male; kings, nobility, popes, bishops, and the Four Horsemen of the Apocalypse ride. For women, riding is associated with the Whore of Babylon, the epitome of female evil, who wreaks havoc by claiming a male activity.

${ }^{38}$ See also Behringer (2008).
} 


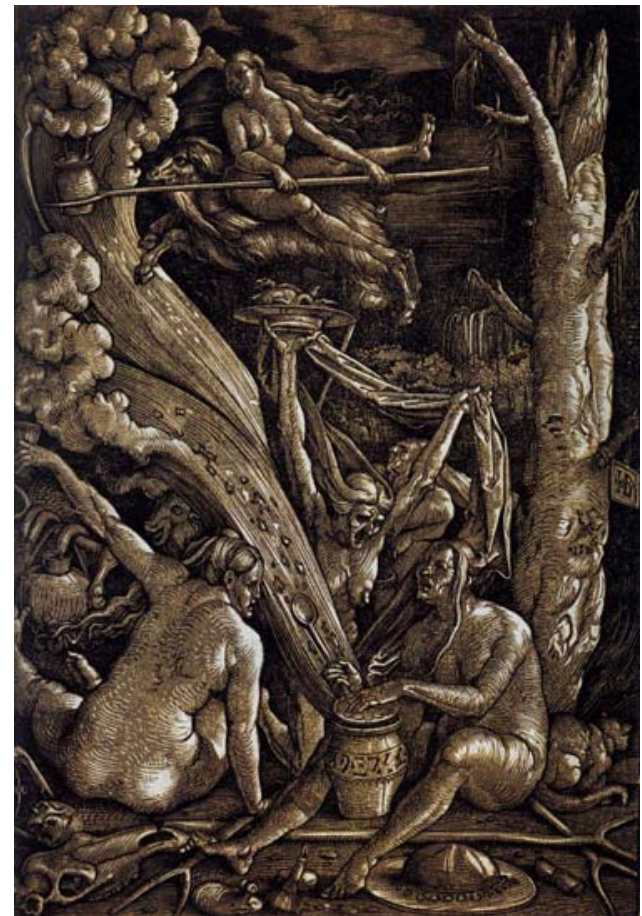

Figure 4. Witches Sabbath (tonal woodcut). Source: Hans Baldung Grien, 1510, Germanisches National museum, Nürnberg.

Both Baldung and Dürer made pictures of witches, though Baldung's are more violent and numerous. The artists were not necessarily personally interested in witches, but their art indicates that they saw the utility of depicting them (Hults, 2005, p. 74). Baldung's witch pictures include paintings, prints, and delicate, meticulous drawings of lewd and pornographic scenes. ${ }^{39}$ Baldung returned to witch imagery throughout his career, and suggesting he had a receptive audience. The scale and delicacy of the media and skill of execution suggest that Baldung's witch images were costly and meant for occasional viewing in private or in small groups (Koerner, 1993, 344-351). Viewing such images was good for, in Hults' words, "male bonding” among his elite audience of viewers (Hults, 2005, pp. 61-62, 93). ${ }^{40}$ Baldung's pictures gave viewers a chance to feel both entertained and superior.

The problem of witchcraft returns us to the idea of perception and the reliability of visual experience. The problem with witches is at least in part a problem of epistemology. Witches existed hidden in plain sight. They were visible only in images and at executions (Wood, 2006, p. 153). How do we then know they exist if only the results of their alleged witchcraft are visible? One may see the effects of witchcraft, e.g. sickness, impotence, draught, hail, still-born children, ${ }^{41}$ but one never saw the practice of witchcraft itself. Witchcraft works like magic. The scarf goes into the hat and the rabbit comes out, but no one actually sees the scarf transform into the rabbit; similarly draught and famine are visible, but the spell that ostensibly caused them is not. Witch trials hinged upon the possibility that demonic seduction and participation in Sabbaths occurred entirely in the mind of the witch (Rowlands, 2008, p. 149). This explains why witches could be convicted even if the accused was asleep in her bed at the time of the supposed Sabbath, because the Sabbath was a mental

\footnotetext{
${ }^{39}$ His 1510 Witches Sabbath was influential enough to be copied by other artists, for instance Urs Graf.

${ }^{40}$ Hults (2005) writes "Put bluntly, Dürer'sFour Witches expresses men’s need to control female sexuality” (p. 65). On witch imagery in the 17th century, see Swan (2005).

${ }^{41}$ On Witches and Seers and the Book of Virtues 1486.
} 
distortion caused by the devil. Despite the accident of the physical location of the accused witch, the evil of her delusion sufficed for conviction.

Thus the Strasbourg preacher Johann Geiler von Kaisersberg in his 1509 series of Lenten sermons explains: ${ }^{42}$

Now you ask me, what do you say, preacher, about these women who travel through the night and meet at assemblies? ...

...I say that they do travel hither and yon, but that they also remain where they are, because they dream that they travel, since the devil can create an impression in the human mind, and thus a fantasy.... And let us not be amazed that he can deceive them so completely... (Kors \& Peters, 2001, p. 237)

Luther's responses to the events at Regensburg depend on the idea that experiences deceives. Just as what seems to be miracles may in fact be satanic deception, witchcraft accusations are grounded in a likelihood of misapprehension. Misogyny and the unreliability of sensory perception combine to imply a skeptical viewing habit among male viewers of female subjects. The author's point is that this propensity to doubt could lead to questioning nothing less than the virginity of the Virgin, especially with Baldung's deliberate confusion of visual cues.

Wood postulates just this skepticism by linking Madonna pictures to Dossi's “Sorceress", which he understands as an image of a witch inscribed on the model of a Madonna in a landscape, as we saw above. By placing a witch in the pose and setting of the Virgin, Dossi's picture threatens to prove that the Virgin herself may have possessed dangerous beauty. ${ }^{43}$ The "Madonna with Parrots" hovers close enough to convention that the viewer knows who she is supposed to be; yet the details undermine all expectations. Just as the Virgin may not be what she seems, so the woman in the world who appears unremarkable may turn out to be a witch. The mood of the "Madonna with Parrots" is something akin to Berthold Brecht's Verfremdungseffekt or estrangement effect (Brecht \& Jeske, 1999), where the audience is left to reconcile itself to what is presented.

Baldung's images of Eve, witches and the "Madonna with Parrots" interconnect thematically. Small witch drawings used scatological and sexual subjects to solidify the identity of a male audience, creating "a world for them to master” (Hults, 2005, p. 91). Witch and Eve imagery create an arena to neutralize anxieties about the crushing power of the male libido through cartoonish depictions of female wickedness. The "Madonna with Parrots" embodies purity tainted with eroticism. The unreliability of parrots' speech adds to the picture's other eccentricities by alluding to the idea of words deprived of familiar meaning, like the familiar meaning lost in the Virgin herself.

\section{Originality}

Christopher Wood's insightful ideas about originality, identity, and understanding of historical time in the Renaissance help explain the Virgin's lost holiness (Wood, 2008) ${ }^{44}$ It is of course a truism, even a cliché, that artistic identity is born of the Italian Renaissance, either through a process of self discovery (Burckhardt, Middlemore, \& Goldscheider, n.d.) or self production (Greenblatt, 1980). Building on the secularization

\footnotetext{
${ }^{42}$ The sermons were later published under title die Emeis(The Ants) Zika (2007, p. 13).

43 "The pagan thematics of the beautiful but deceptive surface were already negatively inscribed into the personage of the Virgin Mary, for Mary was the one woman whose beauty did not deceive. The picture works backwards and discloses the pagan and magical dimensions of the Christian figure” (Wood, 2006, p. 167).

${ }^{44}$ His argument hinges on a distinction between notions of history and truth before and after the advent of mechanically reproducible media.
} 
paradigms developed by Jakob Burckhardt, Aby Warburg, and Hans Belting, among others, ${ }^{45}$ Wood proposes a concept of artistic identity based on a distinction between works of art and literature that are "merely" authored, i.e. original creations of a single imagination and a particular moment in the timeline of history, compared to images and objects that draw power and truth from explicit continuity with oral and written traditions. ${ }^{46}$ This is not a move from sacred to secular so much as a shift from one kind of visual knowledge to another. Works of art and literature that perpetuate a tradition with no assertive authorial presence, such as a signature, a date, a recognizable personal style or an intentional deviation from conventional style or content, evolve out of an ongoing, uncreated past. Such images and objects link "have-always-been" to "will-always-be", each functioning as a fungible replacement for a preceding object. A later copy of an earlier image is, for all epistemological, devotional, and historical purposes, precisely that earlier image itself, despite the accidents of the time of its literal manufacture. The rupture in an ongoing connection with the past, the intrusion of a personality in an ongoing change in images is what others have called the birth of the artist or the emergence of the individual (Belting 1994; Burckhardt, n.d.; \& Greenblatt, 1980).

The fulcrum of the shift from uncreated artifact to single work of art is the notion of the individual author who is the product of a fixed historical moment. The introduction of an identifiable artist, known either by style, signature, date, or deviation from tradition, forces the viewer to grapple with sad knowledge that earlier replicas were never actually equivalent to their antecedents. At best, the magic of the past has simply disappeared. At worst, no magic was ever present at all (Wood, 2006, pp. 151, 153).

Wood distinguishes between Artifact, i.e. an object whose primary function is devotional and tends to be consistent with the past versions of the subject, and Art, whose devotional function may coexist with, or disappear behind, expressions of artistic originality and identity. For the former the primary issue is consistency of form, which preserves the devotional power and recedes all the way back to a holy and powerful original. Consistency of form conserves function and holiness. The replica does not merely replace the original, it is the original. The incidental maker of the object at any given historical moment is merely a conduit in a more important chain of meaning, the substitutional chain.

The advent of mechanical reproducibility discredited the substitutional model. The seeming exactness of a published text or printed image revealed the inevitable imperfection of the earlier hand-made substitutions, obliging viewers to focus on what made the substitutions unique rather than what bound them to a common origin. No longer an Artifact that could substitute, the Art object was unique and irreplaceable. ${ }^{47}$ This notion of originality replacing sustained holiness unlocks the mystery of the "Madonna with Parrots". The profanation we observe with Baldung depends on broken substitutional chain, such that the "truth" and "holiness" of repetition has been sacrificed to the profanity of originality. By this definition the "Madonna with Parrots" is "Art" because it showcases the creativity of the maker and the content as invention or fiction (Wood, 2006, p. 156). ${ }^{48}$

The "Madonna with Parrots" presents a case of representational agnosticism where anything is possible

\footnotetext{
45 See Woods' (2006) rehearsal of this literature in Forgery (pp. 76-84).

${ }^{46}$ Wood (2006) makes this argument based on his reading of "Orlando Furioso" by Ludovico Ariosto, court poet to Alfonso d'Este. Ariosto recognized that his own poem is "merely" authored, that it does not have the strength of the oral tradition that supports Romances (p. 151).

${ }^{47}$ For a full explanation of these ideas, see Wood (2006) “Germany and Renaissance” and Belting (1994). For Wood's critique of Belting and the secularization paradigm, see Wood (2006, pp. 76-79)

${ }_{48}$ Witch images are German book illustrations or “collectible works of art”, see Barry, Hester, \& Roberts, 1996.
} 
because the substitutional chain is broken, the sacred and un-created artifact exposed as a loss or a lie, and unfettered imagination is all that remains. The Madonna with Parrots exemplifies this dilemma. The picture "excavates" levels of "Marian myth" by reflecting backwards to reveals the man behind the curtain, as it were. She is the issue of imagination that dares to profane the formulaic representation of the Virgin. The figure then becomes a showcase for such newfangled notions as originality and artistic self-awareness that ruptures tradition.

This idea of invention expands the association between witch imagery the "Madonna with Parrots", and Baldung's celebrated witch imagery. Both are also inventions/fictions that showcase Baldung's individuality and creativity, even though such imagery will ultimately justify real prosecutions of witches. These fictions still point to "truths" outside themselves—-such as the belief that women are inferior to men. But there is no retinal "truth" in the pictures per se. ${ }^{49}$ Neither the witches nor the "Madonna with Parrots" recapitulates a holy original. The "Madonna with Parrots" is "self-differentiated" from cult images of the Virgin, and has become unreliable, even dangerous. ${ }^{50}$

\section{Venus}

In addition to Eve and Witches, Venus imagery also factors in to the meaning of the "Madonna with Parrots". ${ }^{1}$ The Virgin and Venus are the beauty queens of their respective traditions. Both of them use eye contact, though generally for quite different purposes, to engage the viewer (Weber am Bach, 2006, p. 130). What the author shall contend in this section is that in the case of the "Madonna with Parrots", the Virgin and Venus have another important similarity: neither retains her sacred status.

If we consider examples of Renaissance images of Venus, for instance Botticelli's canonical Birth of Venus of c. 1480, Uffizi Museum, Florence or any number of Venus images from the Cranach workshop, what we see is a palimpsest, layers of meaning, much of it Christian, upon an imagined picture of a pagan goddess. Neither Botticelli nor Cranach tells us anything about the "real” Venus. The "Madonna with Parrots" tells us just as little about the "real" Virgin.

In her indispensible 2006 study of the Madonna images of Hans BalungGrien, Sibylle Weber-am-Bach has rightly observed formal parallels between "Madonna with Parrots" and depictions of Venus. The gesture of the hand across the chest in the "Madonna with Parrots" parallels the composition of such famous objects as the Medici Venus, 2nd century BCE, Uffizi, Florence, among almost countless other examples. ${ }^{52}$ For Weber am Bach, these parallel gestures between the Virgin and Venus assert the Virgin's beauty as erudite flattery for cognoscenti, that is, educated Humanists who will recognize the parallels with Venus and understand that the Virgin is as beautiful as the pagan goddess of love. ${ }^{53}$ Given these formal parallels and the Humanist context of Strasbourg, Weber am Bach concludes that the woman in the picture is not simply lovely as Venus, but she

\footnotetext{
${ }^{49}$ As Wood (2006) writes in an essay on DossoDossi, "The witch emerged as a subject in European art in the late fifteenth century, at the very moment when the sacred image was beginning to lose its automatic centrality within the careers of artists and the imaginations of patrons” (p. 151).

${ }^{50}$ In its threat to the artifact, the beautiful Maga is dangerous. Cult images "had offered the image of the Madonna, for example, as a reliable guide to her essence. The image of the maga also offered a beautiful surface, but signaled, through its self-differentiation from the cult image, that appearance itself was unreliable” (Wood, 2006, p. 164).

${ }^{51}$ On the relationship between Venus and the Virgin, see Weber am Bach (2006, pp. 164-166). Weber am Bach understands Baldung's comparison between the Virgin and Venus as a way to signify the artist's Humanist and appeal.

52 On the Virgin and Venus, see (Weber am Bach, 2006, pp. 18, 122-124, 130).

${ }^{53}$ Baldung uses the Venus and Madonna together implicitly to compare himself to Apelles; Baldung's Virgin is the aesthetic counterpart to Apelles’ Venus. Weber am Bach (2006, p. 163).
} 
actually is Venus herself (Weber am Bach, 2006, p. 70), a fact that would explain the figure's sensuality.

As an alternative to Weber am Bach's argument, I contend instead that the Virgin may be as lovely as Venus, but she does not in fact dissolve into Venus. Formal parallels between subjects do not nullify the identities of each subject. For instance, the male and female figures in Dürer's Adam and Eve engraving of 1504 echo the "Medici Venus" and the "Apollo Belvedere" 330-320 BCE, Vatican Museums without literally transforming the first parents into pagan figures. Similarly, the composition of the "Madonna with Parrots" obviously depicts the Virgin Mary, all the willful distortions notwithstanding.

The Virgin in 16th-century Strasbourg parallels Venus in 15th-century Florence. Both are artifacts that have lost living votive function and form part of a longing for an idealized past. The question of whether Baldung believed in the Virgin, or witches for that matter, is as immaterial as whether Botticelli worshipped Venus.

If Baldung's picture informs the viewer that the Virgin's beauty rivals that of Venus, the picture also tells the viewer that the Virgin and Venus are equally fictitious. Idea of Hults and van der Osten's claim that the Virgin has become art make perfect sense. Formal parallels between Venus and the Virgin indicate that both have receded into mythical status. ${ }^{54}$

Luther's notion of the Virgin as worthy but not holy suffices to support this idea, but the style of the "Madonna with Parrots" makes the point by departing from Marian tradition and appropriating qualities of a discredited pagan holy figure. Severed from the formal and functional connections that defined her doctrinal meaning, she is now, like Venus, a subject that the artist may manipulate to showcase his originality and identity (Weber am Bach, 2006). She is the Virgin consigned to the status of myth.

\section{Conclusion}

The parrot, the bird associated with Eve and the Virgin, that Dürer drew and then reversed when it was placed in the 1504 Adam and Eve engraving, is the perfect symbol of lost innocence. Parrots were "exotic" by 16th-century standards. Their speech was magical, their colors Edenic. Companion of both Eve and the Virgin, the parrot may signify the two women combined. The sensual neck biting in Baldung's painting epitomizes the multiple valences of paradise and Virginity.

Baldung's "Madonna with Parrots" offers the viewer a range of ideas and pleasures: color, beauty, pictorial familiarity and challenges to that familiarity, theological truisms and provocative violations of those truisms, eroticism, and a general warning to beware of all women, including the Virgin, whom Luther characterized as "like any other". In short, the viewer is comforted, amused, provoked, admonished and entertained. The admonition to beware of women doubles as a congratulatory pat on the back for being one of the superior sex. Hults' observation about Baldung's witches applies here as well, that the female figure “...confirmed everything that men aspired to by representing all that they struggled to reject” (Hults, 2005, p. 96). ${ }^{55}$

The Virgin's, sexual presentation—within the framework of Lutheran demotion of her status, formal

\footnotetext{
${ }^{54}$ Baldung synthesizing the Virgin with Venus is Neoplatonism in reverse-not reconciling pagan belief to dovetail with Christianity, but consigning Christianity to the status of antiquity, of art rather than artifact "Baldung's 1510 woodcut, along with Dürer's Witch, made it possible to visualize a deadly stereotype, regardless of whether artists themselves fully believed in it" (Hults, 2005, pp. 81-82). Or in Belting's (1994) memorable formulation "If Venus and Cupid were shown on the kind of panel that had previously been the monopoly of saints, it could be justified only by granting art the same freedom as poetry to create fictions, beautiful illusions. An image of Venus that was not a work of art would have been outright nonsense” (p. 472).

${ }_{55}$ Koerner (1993) proposes a scenario that is diametrically opposed, where the viewers of Baldung's Adam and Eve painting in Lugano are not elevated, but denigrated in its presence (p. 298).
} 
parallels with Eve and Venus, the visual cues that render her purity dubious, and a fear of unreliable senses-makes for an uncomfortable realization. Like Adam and Eve who ate the fruit and realized they had been naked all along, the viewer of Baldung's picture must recognize that the Virgin may never have been pure.

The parrot is a conundrum, a talking animal whose words cannot be trusted and a symbol whose conflicting valences complement the sensual Virgin in Baldung's painting. As Mark Twain observes with characteristic succinctness: "She was not quite what you would call refined. She was not quite what you would call unrefined. She was the kind of person that keeps a parrot” (Twain, 2008, p. 29).

\section{References}

Andersson, C. (1981). Religiöse Bilder Cranachsim Dienst der Reformation (Cranach's Religious Images in the Service of the Reformation). Humanismus und reformation alskulturelle Kräfte in der deutschen Geschichte (Humanism and Reformation as Cultural Forces in German History). (pp. 43-79). Berlin and New York: Walter de Gruyter.

Baldung, G. H. (2009). Grove encyclopedia of northern Renaissance art (Vol. 1). G. Campbell (Ed.). Oxford: Oxford University Press.

Baldung, H., Marrow, J. H., \& Shestack, A. (1981). Hans Baldung Grien, prints \& drawings: National Gallery of Art. New Haven: Yale University Art Gallery.

Barry, J., Hester, M., \& Roberts, G. (1996). Witchcraft in early modern Europe: studies in culture and belief. Cambridge: Cambridge University Press.

Bartrum, G. (1995). German Renaissance prints, 1490-1550. London: British Museum Press.

Baxandall, M. (1980). The Limewood Sculptors of Renaissance Germany. New Haven: Yale University Press.

Behringer, W. (2008).Weather, Hunger, and Fear. In D. Oldridge, Reader (pp. 74-85). London; New York : Routledge.

Belting, H. (1994). Likeness and presence. Chicago: University of Chicago Press.

Berdini, P. (1997). The religious art of Jacopo Bassano: Painting as visual exegesis. Cambridge and New York: Cambridge University Press.

Bleyerveld, Y. (2001). Chaste, Obedient and Devout: Biblical women as patterns of female virtue in Netherlandish and German graphic art, ca. 1500-1750. Simiolus, 28, 219-250.

Boehrer, B. (2004). Parrot culture. Philadelphia: University of Pennsylvania Press.

Boehrer, B. T. (2010). Animal characters: Nonhuman beings in early modern literature. Philadelphia: University of Pennsylvania Press.

Brady, T. (1975). The social place of a German Renaissance artist: Hans Baldung Grien (1484/5-1545). Central European History, 8, 295-315.

Brecht, B., \& Jeske, W. (1999). Mutter Courage und ihre Kinder: eine ChronikausdemDreissigjahrigen Krieg (Mother courage and herchildren. A chronical from theThirty-YearsWar). Frankfurt: Suhrkamp.

Bulfinch, T. (2004 PDF). Introduction. In P. Gutenberg, Bulfinch's Mythology (pp. 9, 234). Retrieved from http://www.sacred-texts.com/cla/bulf/bulf00.htm

Burckhardt, J., Middlemore, S. G. C., \& Goldscheider, L. (n.d.). The Civilization of the Renaissance in Italy. Vienna: Phaidon Press.

Bussmann, G. (1966). Manierismusim Spatwerk Hans Baldung Griens; die Gemailde der zweiten Strassburger Zeit (Mannerism in the late work of Hans Baldung Grien: Paintings of the second Strasbourg period). Heidelberg: C. Winter.

Cohen, S. (2008). Animals as disguised symbols in Renaissance art. Leiden and Boston: Brill.

Davis, W. (2009). The subject in the scene of representation. The Art Bulletin, 76, 571.

Dillenberger, J. (1961). Introduction to Martin Luther: Selections from his writings (p. xiii). J. Dillenberger (Ed.). Garden City, N.Y.: Anchor Books.

Düffel, H. (1968). Luthers Stellungzur Marienverehrung. Kirche und Konfession (Luther's position on adoration of Mary. church and confession) (vol. 13). Göttingen: Vandenhoeck \& Ruprecht.

Eisler, C. T. (1991). Dürer's animals. Washington: Smithsonian Institution Press.

Falkenburg, R. L. (1999). Calvinism and the emergence of Dutch seventeenth-century landscape art-A critical evaluation. In P. C. Finney (Ed.), Seeing beyond the word: Visual arts and the Calvinist tradition (p. 356). Grand Rapids, Mich.: William B. Eerdmans Publishing.

Freedberg, D. (1989). The power of images. Chicago: University of Chicago Press. 
Goedde, L. (1989). Tempest and shipwreck in Dutch and Flemish art: Convention, rhetoric, and interpretation. Philadelphia: University Park: Pennsylvania State University Press.

Graef, H. (1963). Mary: A history of doctrine and devotion (Vol. 2). New York: Sheed and Ward.

Greenblatt, S. (1980). Renaissance self-fashioning: From more to Shakespeare. Chicago: University of Chicago Press.

Harbison, C. (1985). Visions and meditations in early Flemish painting. Simiolus, 15, 87-119.

Harbison, C. (1994). Sexuality of Christ in the Early Sixteenth Century in Germany. In A Tribute to Robert A. Koch: Studies in the Northern Renaissance (pp. 70-81). Princeton: Department of Art and Archaeology, Princeton University.

Heal, B. (2001). A woman like any other? Images of the Virgin Mary and Marian devotion in Nuremberg, Augsburg, and Cologne, c. 1500-1600 (Ph.D. Thesis, University of London (Courtauld Institute of Art)).

Heal, B. (2007). The cult of the Virgin Mary in early Modern Germany: Protestant and Catholic piety, 1500-1648. Cambridge, UK: Cambridge University Press.

Hugelshofer, W. (1969). Wiederholungenbei Baldung (Baldung’s repetitions). Zeitschriftfür Kunstgeschichte, 32, 29-43

Hults, L. C. (2005). The Witch as Muse art, gender, and power in early Modern Europe. Philadelphia: University of Pennsylvania Press.

Koerner, J. (1993). The moment of self portraiture in German Renaissance Art. Chicago: University of Chicago Press.

Kors, A. C., \& Peters, E. (2001). Witchcraft in Europe, 400-1700: A documentary history. Philadelphia: University of Pennsylvania Press.

Lohse, B. (1986). Martin Luther: An introduction to his life and work. (R. C. Schultz, Trans.). Philadelphia: Fortress Press.

Luther, M. (1912-1921). Martin Luthers Werke: Kritische Gesammtausgabe; Abteilung Tischreden (Martin Luther's works: Complete critical edition; section table talk) (Vol. 6). Weimar: Hermann Böhlaus Nachfolger.

Luther, M. (1955-1986). Works (Vols. 55). In H. T. Lehmann, J. Pelikan, \& H. C. Oswald (Eds.). Philadelphia: Fortress Press.

Marrow, J. (1986). Symbol and Meaning in Northern European Art of the Late Middle Ages and the Early Renaissance. Simiolus, 16, 150-169.

Mielke, H. (1988). Albrecht Altdorfer: ZeichnungenDeckfarbenmalereiDruckgraphik (Albrecht Altdorfer: Drawings, ceiling decorations, and graphic work). Berlin: Reimer Verlag.

Molitor, U. (1490-1510). On Female Witches and Seers. Berlin: ReimerVerlag.

Noble, B. (2009). Lucas Cranach the Elder: Art and devotion of the German reformation. Lanham: Rowan and Littlefield Group and Co..

Oberman, H. (1994). The Virgin in Evangelical perspective. The impact of the reformation (p. 242 and n. 64). Grand Rapids, Mich.: William B. Eerdmans Publishing Company.

Pepperberg, I. M. (2008). Alex \& Me: How a scientist and a parrot discovered a hidden world of animal intelligence-and formed a deep bond in the process. New York, NY: Collins.

Rowlands, A. (2008). A Lutheran response to witchcraft and magic. In D. Oldridge (Ed.), The Witchcraft Reader (2nd ed.) (p. 149). New York, NY: Routledge.

Schade, S. (1983). Schadenzauber und die Magie des Körpers: Hexenbilder der fruhen Neuzeit (Dark magic and the enchantentment of the body: Early modern images of witches). Worms: Werner's che Verlagsgesellschaft.

Schreiner, K. (1994). Maria: Jungfrau, Mutter, Herrscherin. München: C. Hanser.

Schütte, K. (2000). Die Madonna Mit Dem Papagei Von Hans BalgungGrien (The Madonna with the Parrot by Hans Baldung Grien) (Unpublished Master's thesis). Bonn

Steinberg, L. (1997). The sexuality of Christ in Renaissance art and in Modern Oblivion (2nd ed.). Chicago: University of Chicago Press.

Sullivan, M. A. (2000). The witches of Dürer and Hans Baldung Grien. Renaissance Quarterly, 53, 333-401.

Swan, C. (2005). Art, science, and witchcraft in early Modern Holland: Jacques de Gheyn II (1565-1629). New York, NY: Cambridge University Press.

Tappolet, W. (1962). Das Marienlob der Reformatoren (Marien devotion of the reformers). Tübingen: Katzmannverlag.

Twain, M. (2008). Following the Equator; Pudd'nhead Wilson's New Calendar cited in Mira Tweti, Of Parrots And People: The Sometimes Funny, Always Fascinating, and Often Catastrophic Collision of Two Intelligent Species (New York: Viking:) 29.

von der Osten, G. (1983). Hans Baldung Grien: Gemälde und Dokumente (Hans Baldung Grien: Paintings and documents). Berlin: Deutscher Verlag für Kunstwissenschaft.

von Dülmen, R. (Ed.). (1987). Hexenwelten: Magie und Imagination vom 16-20 Jahrhundert. Frankfurt: Fischer TaschenuchVerlag.

Walsch, K. (1981). The Works of Bernard of Clairvaux (Vol. 2). On the Song of Songs I. Cistercian Fathersseries, No. 4. 
Kalamazoo: Cistercian Publications, Inc..

Weber am Bach, S. (2006). Hans Baldung Grien (1484/85-1545): Marienbilder in der Reformation. Studien zur christlichen Kunst (Hans Baldung Grien (1484-85):Marian images in the reformation. Studies on christian art) (Vol. 6). Regensburg: Schnell \& Steiner.

Wittmann, J. (1998). Die Bedeutung des Marienbildesim Schaffen Cranachs (The meaning of Marian images in Cranach’s oeuvre). In I. Sandner, (Ed.), Unsichtbare Meisterzeichnungen auf dem Malgrund: Cranach und seine Zeitgenossen (Invisible master drawings on the painting surface: Cranach and his contemporaries) (p. 171). Regensburg: Schnell \& Steiner.

Wood, C. (2006). Countermagical Combinations by Dosso Dossi. Anthropology and Aesthetics, 49(50), 153.

Wood, C. S. (2008). Forgery replica fiction. Temporalities of German Renaissance art. Chicago and London: University of Chicago Press.

Yarnall, J. (1994). Transformations of circe: The history of an enchantress. Urbana and Chicago: University of Illinois Press.

Zika, C. (2002). Images of Circe and discourses of witchcraft: 1480-1580. Retrieved from http://www.zeitenblicke.historicum.net/2002/01/zika/zika.html

Zika, C. (2007). Appearance of witchcraft. Print and Visual Culture in Sixteenth-Century Europe. London: Routledge.

Zika, C. (2014). Images and Witchcraft studies: A short history. In M. Nenonen, Writing Witch-Hunt histories: Challenging the paradigm (pp. 41-85). Leiden and Boston: Brill. 